\title{
Erwinia carotovora subsp. odorifera subsp. nov., Associated with Odorous Soft Rot of Chicory (Cichorium intybus L.)
}

\author{
ANNIE GALLOIS, ${ }^{1}$ REGINE SAMSON,${ }^{2 *}$ ELISABETH AGERON, ${ }^{3}$ AND PATRICK A. D. GRIMONT ${ }^{3}$ \\ Laboratoire de Recherches sur les Arômes, Institut National de la Recherche Agronomique, 21034 Dijon \\ Cedex, ${ }^{1}$ Station de Pathologie Végétale et Phytobactériologie, Institut National de la Recherche \\ Agronomique, 49070 Beaucouzé, ${ }^{2}$ and Unité des Entérobactéries, Institut National de la Santé \\ et de la Recherche Médicale Unité 199, Institut Pasteur, 75724 Paris Cedex $15,{ }^{3}$ France
}

\begin{abstract}
Eleven strains of Erwinia carotovora that were isolated mainly, but not exclusively, from slimy rot of witloof chicory and were previously designated "atypical" $E$. carotovora subsp. atroseptica strains were characterized and compared with strains of $E$. carotovora subsp. carotovora, $E$. carotovora subsp. atroseptica, and Erwinia chrysanthemi (including the type strains). The 11 atypical $E$. carotovora subsp. atroseptica strains produced a typical bananalike odor when they were inoculated onto witloof chicory leaves. DNA-DNA homology experiments, biochemical tests, tests to determine carbon utilization patterns, and tests to identify the volatile metabolites produced from rotting witloofs were performed. The volatile end products of witloof decay were analyzed by gas chromatography. Alcohols, methylketones, and ethylacetate were produced by all of the Erwinia strains which we studied, whereas propyl acetate, isobutyl acetate, isoamyl acetate, and 2-actamyl acetate were produced only by the flavoring witloof soft-rot strains. A DNA relatedness study was performed by hybridizing DNAs with a tritium-labeled DNA and estimating the $\Delta T_{m}$ values $\left(\Delta T_{m}\right.$ is the difference between the thermal denaturation midpoint of a homoduplex and the thermal denaturation midpoint of a heteroduplex). The 11 flavoring strains constituted a tight DNA hybridization group (79 to 91\% related to type strain CFBP 1878 isolated from witloof). Strains of $E$. carotovora subsp. carotovora were 59 to $88 \%$ related to strain CFBP $1^{1878} \mathrm{~T}$ ( $T=$ type strain) $\left(\Delta T_{m}\right.$ range, 3 to $\left.4.5^{\circ} \mathrm{C}\right)$, indicating that they belonged to the same species but another subspecies. $E$. carotovora subsp. atroseptica and $E$. carotovora subsp. betavasculorum appeared to be less closely related to strain CFBP $1878^{\mathrm{T}}$ than $E$. carotovora subsp. carotovora was, exhibiting $53 \%$ homology $\left(\Delta T_{m}, 7^{\circ} \mathrm{C}\right)$ and 48 to $51 \%$ homology $\left(\Delta T_{m}, 8.5^{\circ} \mathrm{C}\right)$, respectively, with strain $C F B P 1878^{\mathrm{T}}$. Therefore, we propose that the 11 flavoring strains are members of a new subspecies, Erwinia carotovora subsp. odorifera. We examined 95 biochemical characteristics, API strip tests, and assimilation tests in Biotype galleries and identified nine tests which can be used for phenotypic differentiation of the new subspecies.
\end{abstract}

Soft rot of witloof (broad-leaf chicory, Cichorium intybus L.) occurs indoors during forcing of the plants. First observed in France (16), this disease typically results in watersoaked, translucent, wet rot of the etiolated leaves and is called "slimy rot" (20). The bacterium that is responsible for this plant tissue maceration disease was designated "atypical" Erwinia carotovora subsp. atroseptica by Samson et al. (16) since a few of its characteristics did not exactly coincide with the characteristics of the potato blackleg pathogen.

The development of slimy rot in witloof chicories has been shown to be always associated with the production of a sweet, ripe, bananalike odor (2). Similar bacteria have been isolated from other soft-rotted plants, such as leeks (Allium porrum) and celery (Apium graveolens); these organisms also produce a bananalike odor when they are inoculated onto witloof leaves. Strains identified as Erwinia chrysanthemi have also been isolated from a soft rot of chicory roots, a disease which may occasionally develop in the field or before forcing of the cut roots.

The purposes of this work were (i) to examine the taxonomic position of strains associated with odorous soft rot of witloof by performing DNA hybridization experiments, (ii) to characterize by using phenotypic tests the odorous softrot organism, and (iii) to identify the volatile metabolites that are responsible for the bananalike odor. Our findings resulted in the description of a new subspecies, Enwinia carotovora subsp. odorifera.

\footnotetext{
* Corresponding author.
}

\section{MATERIALS AND METHODS}

Bacterial strains. The strains which were used in this study are shown in Table 1. The bacteria were purified on YPD agar (yeast extract, $3 \mathrm{~g}$ /liter; peptone, $5 \mathrm{~g}$ /liter; dextrose, 5 g/liter; $\mathrm{pH}$ 7.2) and were stored during the study on yeast extract-peptone agar slants without dextrose.

DNA relatedness study. DNAs were extracted and purified as described elsewhere (4). The exact procedures used for in vitro labeling of DNA with tritium-labeled nucleotides and for hybridization experiments (S1 nuclease-trichloroacetic acid procedure) have been described previously (13). The temperature at which $50 \%$ of a reassociated DNA became hydrolyzable by $S 1$ nuclease $\left(T_{m}\right)$ was determined as described by Crosa et al. (7). $\Delta T_{m}$ (the difference between the $T_{m}$ of a homoduplex and the $T_{m}$ of a heteroduplex) is an estimate of the level of divergence between two DNAs (3).

Conventional identification tests. The techniques which we used for bacterial identification (Gram and flagellum staining, spore formation, oxidase, dextrose fermentation, nitrate reduction, Voges-Proskauer test, starch hydrolysis, lecithinase and phosphatase tests, indole production, Simmons citrate, esculin hydrolysis, growth at $37^{\circ} \mathrm{C}$ ) were classical techniques $(10,15)$. Additional tests which we used included tests for hydrolysis of L-alanine-4-nitroanilide hydrochloride (6), liquefaction of calcium polygalacturonate in Sutton medium (1), liquefaction of carboxymethyl cellulose (14), and production of reducing substances from sucrose (9). Production of acid from carbohydrates was determined in a mineral medium $\left(\mathrm{NH}_{4} \mathrm{H}_{2} \mathrm{PO}_{4}, 0.1 \% ; \mathrm{KCl}, 0.02 \% ; \mathrm{MgSO}_{4}\right.$. 
TABLE 1. Sources of bacterial strains

\begin{tabular}{|c|c|c|c|}
\hline Strain $^{a}$ & Host plant & Geographical origin & $\begin{array}{c}\text { Source, year of isolation, other designation, } \\
\text { and/or biovar }{ }^{a}\end{array}$ \\
\hline \multicolumn{4}{|l|}{$\begin{array}{l}\text { Erwinia carotovora subsp. odorifera } \\
\text { strains }\end{array}$} \\
\hline CFBP $1878^{T}$ & Cichorium intybus & Loiret, France & R. Samson, 1978 \\
\hline CFBP 1879 & Cichorium intybus & Rhône, France & R. Samson, 1979 \\
\hline CFBP 1880 & Cichorium intybus & Morbihan, France & R. Samson, 1979 \\
\hline CFBP 1892 & Cichorium intybus & Oise, France & L. Gardan, 1978 \\
\hline CFBP 1893 & Apium graveolens & Lot, France & R. Samson, 1976 \\
\hline CFBP 1959 & Cichorium intybus & Pyrénées-Atlantiques, France & R. Samson, 1980 \\
\hline CFBP 2154 & Cichorium intybus & Yvelines, France & R. Samson, 1982 \\
\hline CFBP 2155 & Cichorium intybus & Côtes-d'Armor, France & L. Gardan, 1982 \\
\hline CFBP 3259 & Allium porrum & Maine-et-Loire, France & R. Samson, 1980 \\
\hline CFBP 3260 & Allium porrum & Loire-Atlantique, France & R. Samson, 1980 \\
\hline CFBP 3261 & Allium porrum & Loire-Atlantique, France & R. Samson, 1982 \\
\hline \multicolumn{4}{|l|}{$\begin{array}{l}\text { Erwinia carotovora subsp. carotovora } \\
\text { strains }\end{array}$} \\
\hline CFBP 798 & Daucus carota & United States & L. R. Jones, ATCC 495 \\
\hline CFBP 1535 & Zea mays & Israel & Z. Volcani, 1958, ICPB EA144 \\
\hline CFBP $2046^{\mathrm{T}}$ & Solanum tuberosum & Denmark & E. Hellmers, NCPPB $312^{\mathrm{T}}$ \\
\hline CFBP 2141 & Solanum tuberosum & France & R. Samson, 1978 \\
\hline \multicolumn{4}{|l|}{$\begin{array}{l}\text { Erwinia carotovora subsp. atroseptica } \\
\text { strains }\end{array}$} \\
\hline CFBP 1330 & Solanum tuberosum & United Kingdom & M. C. M. Perombelon, 1971 \\
\hline CFBP $1526^{\mathrm{T}}$ & Solanum tuberosum & United Kingdom & D. C. Graham, NCPPB $549^{\mathrm{T}}$ \\
\hline CFBP 2391 & Solanum tuberosum & Germany & B. Jouan (47), 1976 \\
\hline \multicolumn{4}{|l|}{$\begin{array}{l}\text { Enwinia carotovora subsp. } \\
\text { betavasculorum } \text { strains }^{b}\end{array}$} \\
\hline CFBP 2121 & Beta vulgaris & United States & S. V. Thomson, 1972, UCPB 162 \\
\hline CFBP $2122^{\mathrm{T}}$ & Beta vulgaris & United States & S. V. Thomson, 1971, UCPB $193^{\mathrm{T}}$ \\
\hline \multicolumn{4}{|l|}{ Enwinia chrysanthemi strains } \\
\hline CFBP 1528 & Zea mays & United States & A. Kelman (SR80), 1966, biovar $3^{c}$ \\
\hline CFBP $2048^{T}$ & Chrysanthemum morifolium & United States & W. H. Burkholder, NCPPB $402^{\mathrm{T}}$, biovar 5 \\
\hline CFBP $2052^{d}$ & Zea mays & United States & A. Kelman (SR58), 1970, biovar 3 \\
\hline CFBP 3262 & Cichorium intybus & France & R. Samson (SA77-2), 1981, biovar 5 \\
\hline CFBP 3263 & Cichorium intybus & France & R. Samson (SB50-18), 1982, biovar 5 \\
\hline CFBP 3264 & Cichorium intybus & France & R. Samson (SC72-3), 1983, biovar 1 \\
\hline CFBP 3265 & Cichorium intybus & France & R. Samson (SC72-4), 1983, biovar 1 \\
\hline CFBP 3266 & Cichorium intybus & France & R. Samson (SC72-6), 1983, biovar 1 \\
\hline \multicolumn{4}{|l|}{ Enwinia amylovora ICPB EA178 } \\
\hline $\begin{array}{l}\text { Erwinia cypripedii ATCC } 29267^{\mathrm{T}} \\
\text { Erwinia herbicola (Enterobacter } \\
\text { agglomerans) NCTC } 9381\end{array}$ & Cypripedium sp. & United States & ICPB EC155 \\
\hline Erwinia nigrifluens ATCC 29275 & Juglans regia & United States & E. Wilson, ICPB EN104 \\
\hline Erwinia mallotivora CFBP $2503^{\mathrm{T}}$ & Mallotus japonicus & Japan & M. Goto, 1976, NCPPB $2851^{\mathrm{T}}$ \\
\hline $\begin{array}{l}\text { Erwinia rhapontici NCPPB } 1739 \\
\text { Erwinia salicis ICPB ES102 }\end{array}$ & Rheum rhaponticum & United Kingdom & S. Masser \\
\hline Enterobacter dissolvens NCPPB 2209 & Sorghum vulgare & United States & N. Zummo, 1969 \\
\hline $\begin{array}{l}\text { Enterobacter nimipressuralis NCPPB } \\
2045^{\mathrm{T}}\end{array}$ & Ulmus sp. & United States & J. C. Carter, 1968 \\
\hline
\end{tabular}

${ }^{a}$ CFBP, French Collection of Phytopathogenic Bacteria, Angers, France; ICPB, International Collection of Phytopathogenic Bacteria, Davis, Calif.; ATCC, American Type Culture Collection, Rockville, Md; NCTC, National Collection of Type Cultures, London, United Kingdom; NCPPB, National Collection of Plant Pathogenic Bacteria, Harpenden, United Kingdom; UCPB, University of California Phytopathogenic Bacteria, Berkeley, Calif.

${ }^{b}$ See reference 18 .

$c$ See reference 17

${ }^{d}$ Type strain of $E$. chrysanthemi pv. zeae.

$7 \mathrm{H}_{2} \mathrm{O}, 0.02 \%$; bromothymol blue, $0.008 \%$; carbohydrate, $0.3 \%$ [wt/vol]; pH 6.5) that was derived from ARJ base (15); the preparations were incubated at $25^{\circ} \mathrm{C}$ for 15 days. API $20 \mathrm{E}$ and API 50CHE strips (BioMérieux, La Balme-lesGrottes, France) were inoculated following the manufacturer's instructions. The strips were incubated at $25^{\circ} \mathrm{C}$ for 5 days.

Assimilation tests. Carbon source utilization tests were performed by using Biotype galleries (Biomerieux) containing 99 pure carbon sources (12). A minimal medium $(60 \mathrm{ml})$ provided by BioMerieux was inoculated with $2 \mathrm{ml}$ of a bacterial suspension calibrated to 100 Klett units (McFarland opacity standard no. 3), and the galleries were filled with the seeded mixture. Tests were conducted at $30^{\circ} \mathrm{C}$. The galleries were examined visually for growth daily for 4 days.

Analysis of volatile odorous compounds. The volatile compounds which we analyzed were produced during soft rot of witloof chicories that were inoculated with bacteria. Detached leaves of fresh witloof chicories were disinfected with calcium hypochlorite $(7 \%$, wt/vol) and rinsed twice with sterile water. A $1-\mathrm{ml}$ portion of a bacterial suspension $(5 \times$ $10^{8}$ cells from a 24 -h-old culture per $\mathrm{ml}$ ) was then injected 
into the parenchyma of each leaf. Inoculated leaves (75 g) were kept in sterile humid chambers (500-ml Erlenmeyer flasks closed with cotton plugs) and incubated at $25^{\circ} \mathrm{C}$ for 24 or $48 \mathrm{~h}$ (until complete liquefaction occurred). Leaves inoculated under the same conditions with sterile water were used as controls.

After $0.4 \mathrm{mg}$ of ethyl isobutanoate was added as an internal standard, the Erlenmeyer flasks containing witloof leaves were placed in a $25^{\circ} \mathrm{C}$ water bath and purged with oxygen-free nitrogen (flow rate, $15 \mathrm{ml} / \mathrm{min}$ ) for $1 \mathrm{~h}$. For headspace trapping, a porous polymer (100 $\mathrm{mg}$ of $80 / 100$ mesh Porapak Q; Waters Division, St. Quentin-en-Yvelines, France) was packed into a glass tube (bore, $3 \mathrm{~mm}$; length, $100 \mathrm{~mm}$ ). By using two traps in series, we ascertained that the adsorption capacity of the first trap was not exceeded. The volatile compounds were then eluted from the trap with $300 \mu \mathrm{l}$ of redistilled diethyl ether. A $1-\mu \mathrm{l}$ portion of the solvent solution was directly injected into a gas chromatograph.

The volatile compounds were separated by using a model DI 700 gas chromatograph (Delsi-Nermag Instruments, Argenteuil, France) equipped with an on-column injector (J. \& W. Chromoptic, Montpellier, France) and a flame ionization detector (maintained at $240^{\circ} \mathrm{C}$ ). A $0.90-\mathrm{m}$ uncoated fusedsilica capillary tube was fitted onto the beginning of the fused-silica capillary column (type DB5; $30 \mathrm{~m}$ by $0.32 \mathrm{~mm}$ [inside diameter]; J. \& W. Chromoptic). The film thickness was $1 \mu \mathrm{m}$. The carrier gas was hydrogen $(50 \mathrm{~cm} / \mathrm{s})$. The oven temperature was programmed to increase from 30 to $100^{\circ} \mathrm{C}$ at a rate of $2^{\circ} \mathrm{C} / \mathrm{min}$. Peak areas were measured with a model ENICA 21 integrator (Delsi-Nermag).

Spectra were recorded with a Delsi-Nermag model R10-10 mass spectrometer coupled to a Girdel model 31 gas chromatograph. The fused-silica type DB5 capillary column $(60$ $\mathrm{m}$ by $0.32 \mathrm{~mm}$ [inside diameter]) was connected directly to the ion source (temperature, $150^{\circ} \mathrm{C}$ ). The operating gas chromatography conditions were the same as those described above. Mass spectra were recorded at $70 \mathrm{eV}$. The scanning rate was $0.8 \mathrm{~s}$ from 25 to 300 a.m.u. All identifications were confirmed by injecting reference compounds.

\section{RESULTS}

DNA-DNA hybridization. The relative levels of reassociation between unlabeled DNAs from Erwinia species and labeled DNA from witloof isolate CFBP $1878^{\mathrm{T}}$ ( $\mathrm{T}=$ type strain) are shown in Table 2 . The atypical $E$. carotovora strains that caused flavoring soft rot of witloof were 79 to 91\% related to strain CFBP $1878^{\mathrm{T}}$. The least closely related strain exhibited $0.5^{\circ} \mathrm{C}$ divergence $\left(\Delta T_{m}\right.$ value) with strain CFBP $1878^{\mathrm{T}}$. Thus, the atypical $E$. carotovora strains that cause flavoring soft rot of witloof constituted a tight DNA hybridization group.

Strains of $E$. carotovora subsp. carotovora were 59 to $88 \%$ related to strain CFBP $1878^{\mathrm{T}}$, with $\Delta T_{m}$ values ranging from 3 to $4.5^{\circ} \mathrm{C}$. E. carotovora subsp. atroseptica was $53 \%$ related to strain CFBP $1878^{\mathrm{T}}$, with a $\Delta T_{m}$ of $7^{\circ} \mathrm{C}$. Strains of $E$. carotovora subsp. betavasculorum were 48 to $51 \%$ related to strain CFBP $1878^{\mathrm{T}}$, with a $\Delta T_{m}$ of $8.5^{\circ} \mathrm{C}$. All other Erwinia species (including $E$. chrysanthemi strains isolated from witloof chicory) and the two Enterobacter species which we tested were less than $16 \%$ related to strain CFBP $1878^{\mathrm{T}}$.

Phenotypic characterization of the flavoring witloof soft-rot organism. Conventional identification of the flavoring softrot strains resulted in identification as members of the species Erwinia carotovora (Table 3). The characteristics
TABLE 2. Levels of relatedness between $E$. carotovora subsp. odorifera CFBP $1878^{\mathrm{T}}$ and $E$. carotovora subsp. carotovora and other Enwinia or Enterobacter species

\begin{tabular}{|c|c|}
\hline Source of unlabeled DNA & $\begin{array}{c}\text { Relatedness } \\
\text { with labeled } \\
\text { DNA from strain } \\
\text { CFBP } 1878^{\mathrm{T}}\end{array}$ \\
\hline \multicolumn{2}{|l|}{ Erwinia carotovora subsp. odorifera strains } \\
\hline CFBP $1878^{\mathrm{T}}$ & $100(0.0)^{a}$ \\
\hline 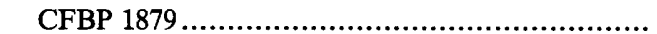 & 80 \\
\hline CFBP $1880 .$. & 90 \\
\hline CFBP $1892 \ldots$ & 91 \\
\hline CFBP $1893 \ldots$. & 83 \\
\hline CFBP $1959 \ldots$ & 85 \\
\hline 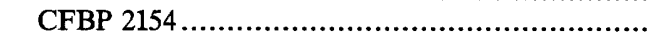 & 81 \\
\hline 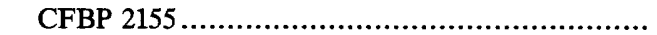 & 88 \\
\hline 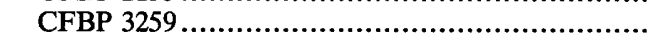 & $79(0.5)$ \\
\hline CFBP $3260 \ldots$. & 89 \\
\hline 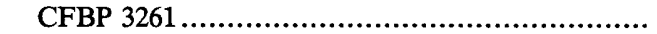 & 81 \\
\hline \multicolumn{2}{|l|}{ Erwinia carotovora subsp.................................... carotovora strains } \\
\hline CFBP 798 & $88(3.0)$ \\
\hline CFBP 1535. & $58(4.5)$ \\
\hline CFBP $2046^{\mathrm{T}}$ & $68(3.0)$ \\
\hline \multicolumn{2}{|l|}{ Erwinia carotovora subsp. atroseptica } \\
\hline CFBP $1526^{\mathrm{T}}$ & $53(7.0)$ \\
\hline \multicolumn{2}{|l|}{ Erwinia carotovora subsp. betavasculorum strains } \\
\hline 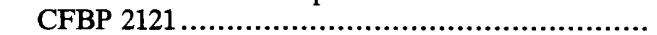 & 51 \\
\hline CFBP $2122^{\mathrm{T}}$ & $51(8.5)$ \\
\hline \multicolumn{2}{|l|}{ Erwinia chrysanthemi strains } \\
\hline CFBP $1528 \ldots \ldots \ldots \ldots \ldots \ldots$ & 14 \\
\hline CFBP $2048^{\mathrm{T}}$ & 13 \\
\hline CFBP $3262 \ldots .$. & 15 \\
\hline 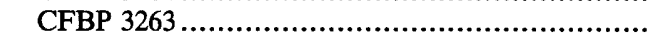 & 12 \\
\hline 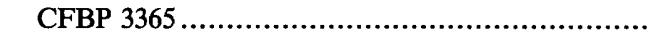 & 15 \\
\hline 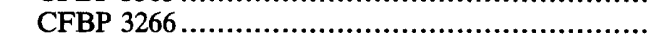 & 16 \\
\hline Erwinia amylovora ICPB EA $178 \ldots$ & 5 \\
\hline Erwinia cypripedii ATCC $29267^{\mathrm{T}} \ldots \ldots \ldots \ldots \ldots \ldots \ldots$ & 10 \\
\hline \multicolumn{2}{|l|}{ Erwinia herbicola (Enterobacter agglomerans) } \\
\hline NCTC $9381 \ldots .$. & 6 \\
\hline Erwinia nigrifluens ATCC $29275 \ldots \ldots . .$. & 18 \\
\hline 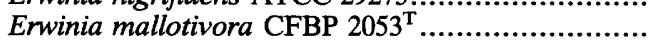 & 5 \\
\hline Erwinia rhapontici NCPPB $1739 . \ldots \ldots \ldots \ldots \ldots \ldots \ldots \ldots \ldots \ldots \ldots \ldots \ldots \ldots$ & 9 \\
\hline 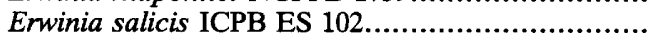 & 8 \\
\hline Enterobacter dissolvens NCPPB $2209 \ldots \ldots$ & 6 \\
\hline Enterobacter nimipressuralis NCPPB $2045^{\mathrm{T}} \ldots$ & 8 \\
\hline
\end{tabular}

a The values in parentheses are $\Delta T_{m}$ values (in degrees Celsius).

common to all of the strains associated with flavoring soft rot of witloof, including the reactions on Biotype strips, are given below in the subspecies description. Some variability was observed (Table 3 ).

Table 4 shows the conventional tests that are useful for phytopathologists and allow differentiation among the $E$. carotovora subspecies, including the odorous soft-rot organism.

Volatile compounds from inoculated witloof chicories. Compounds belonging to three different chemical classes (esters, alcohols, and ketones) were found in the volatile compound profiles of all of the strains (Table 5). None of these compounds was present in the headspace of healthy-leaf preparations. Alcohols, methylketones, and ethylacetate were produced by all of the strains, whereas propyl acetate, isobutyl acetate, isoamyl acetate, and 2-methyl-butyl-(actamyl)-acetate were produced only by the 11 flavoring witloof soft-rot strains.

Isoamyl acetate is well known as the odorous impact compound in bananas and, together with isobutyl acetate 
TABLE 3. Phenotypic characteristics of the erwinias tested ${ }^{a}$

\begin{tabular}{|c|c|c|c|c|c|}
\hline \multirow[b]{2}{*}{ Characteristic } & \multicolumn{5}{|c|}{$\%$ of strains positive } \\
\hline & $\begin{array}{l}\text { E. carotovora } \\
\text { subsp. odorifera } \\
\quad(n=11)^{b}\end{array}$ & $\begin{array}{l}\text { E. carotovora } \\
\text { subsp. carotovora } \\
(n=4)\end{array}$ & $\begin{array}{c}\text { E. carotovora } \\
\text { subsp. atroseptica } \\
(n=3)\end{array}$ & $\begin{array}{c}\text { E. carotovora subsp. } \\
\text { betavasculonum } \\
(n=2)\end{array}$ & $\begin{array}{l}\text { E. chrysanthemi } \\
(n=8)\end{array}$ \\
\hline Lecithinase & 0 & 0 & 0 & 0 & 100 \\
\hline Phosphatase & 0 & 0 & 0 & 0 & 100 \\
\hline Indole production & 0 & 0 & 0 & 0 & 100 \\
\hline $\begin{array}{l}\text { Reducing sugars produced from } \\
\text { sucrose }\end{array}$ & 100 & 0 & 100 & 100 & $50(w)^{c}$ \\
\hline Growth at $37^{\circ} \mathrm{C}$ & 100 & 100 & 0 & 100 & 100 \\
\hline \multicolumn{6}{|l|}{ Acidification of ${ }^{d}$ : } \\
\hline Sorbitol & 100 & 0 & 0 & 0 & 0 \\
\hline$\alpha$-Methylglucoside & 100 & 0 & 100 & 100 & 0 \\
\hline Palatinose & 100 & 0 & 100 & 100 & 0 \\
\hline Melibiose & 100 & 100 & 100 & 0 & 100 \\
\hline D-Arabitol & 100 & 0 & 0 & 0 & 0 \\
\hline Alkalinization of malonate $^{d}$ & 0 & 0 & 0 & 0 & 100 \\
\hline Acid produced from inulin ${ }^{e}$ & 0 & 0 & 0 & 100 & 75 \\
\hline Citrate (Simmons) & 100 & 100 & 100 & 0 & 100 \\
\hline \multicolumn{6}{|l|}{ API $20 \mathrm{E}$ tests } \\
\hline Arginine dihydrolase & 0 & 0 & 0 & 0 & 75 \\
\hline Citrate & 100 & 100 & 100 & 0 & 100 \\
\hline Indole & 0 & 0 & 0 & 0 & 100 \\
\hline Gelatin & 100 & 100 & 0 & 100 & 100 \\
\hline Sorbitol & 100 & 0 & 0 & 0 & 0 \\
\hline Melibiose & 100 & 100 & 100 & 0 & 100 \\
\hline \multicolumn{6}{|l|}{ API 50 CHE tests } \\
\hline D-Arabinose & 0 & 0 & 0 & 0 & 25 \\
\hline Sorbitol & 100 & 0 & 0 & 0 & 0 \\
\hline$\alpha$-Methyl-D-glucoside & 100 & 0 & 100 & 100 & 0 \\
\hline Amygdalin & 9 & 50 & 67 & 100 & 0 \\
\hline Maltose & 45 & 0 & 67 & 100 & 0 \\
\hline Lactose & 100 & 100 & 100 & 100 & 25 \\
\hline Melibiose & 100 & 100 & 100 & 0 & 100 \\
\hline Trehalose & 100 & 100 & 100 & 100 & 0 \\
\hline Inulin & 0 & 0 & 0 & 100 & 75 \\
\hline$\beta$-Gentiobiose & 100 & 100 & 100 & 100 & 12 \\
\hline D-Turanose & 27 & 0 & 67 & 100 & 0 \\
\hline D-Arabitol & 100 & 0 & 0 & 0 & 0 \\
\hline Gluconate & 0 & 0 & 100 & 100 & 0 \\
\hline
\end{tabular}

a The following tests were positive for all of the strains: L-alanine aminopeptidase; peritrichous; dextrose fermentation; nitrate reduction; pectate liquefaction; $\beta$-galactosidase; acetoin production; acid production from glucose, mannitol, inositol, rhamnose, sucrose, amygdalin, and L-arabinose in API 20E tests; and acid production from glycerol, L-arabinose, ribose, D-xylose, galactose, D-fructose, $N$-acetyl-glucosamine, arbutin, esculin, salicin, cellobiose, and D-raffinose in API $20 \mathrm{E}$ or API 50CHE tests. The following tests were negative for all of the strains: Gram reaction; spore formation; oxidase; starch hydrolysis; lysine and ornithine decarboxylases; $\mathrm{H}_{2} \mathrm{~S}$; urease; tryptophan desaminase in API $20 \mathrm{E}$ tests; acid production from erythritol, $\mathrm{L}$-xylose, adonitol, $\beta$-methylxyloside, L-sorbose, dulcitol, $\alpha$-methyl-D-mannoside, melezitose, starch, glycogen, xylitol, D-lyxose, D-tagatose, D-fucose, L-fucose, L-arabitol, 2-ketogluconate, and 5-ketogluconate in API 50CHE tests.

${ }^{b} n$ is the number of strains tested.

$c$ w, weak reaction.

${ }^{d}$ In ARJ basal medium.

e In peptone medium.

and to a lesser extent actamyl acetate, was responsible for the bananalike odor in our study.

\section{DISCUSSION}

Patterns of volatile products are commonly used in taxonomy, especially in the identification of Clostridium spp. (5). In our laboratory, the bananalike odor of infected witloof chicories is a quick test for identification of the slimy rot produced by $E$. carotovora subsp. odorifera. The monitoring of volatile compounds has been proposed as a technique for detecting soft rot in potato tubers (21). The production of volatile metabolites has been studied in potatoes infected with both $E$. carotovora subsp. carotovora and $E$. carotovora subsp. atroseptica (23). Short-chain alcohols and car- bonyl compounds were identified. Most of these compounds were found in our study. Ethyl acetate, a common microbial metabolite which was the most abundant metabolite compound in our study, has also been found in the volatile compound profile of potato tubers inoculated with $E$. carotovora subsp. atroseptica (22). However, none of these metabolites could impart to the diseased plants a bananalike odor. The concentrations of the volatile compounds shown in Table 5 are underestimated since the headspace did not allow accurate measurements. Nevertheless, the three acetates responsible for the bananalike odor (isobutyl acetate, isoamyl acetate, and actamyl acetate) were produced only by the 11 flavoring soft-rot strains when they were grown on witloof chicory leaves. These three acetates could be used to characterize the new subspecies. 
TABLE 4. Phenotypic differentiation of $E$. carotovora subsp. odorifera from other $E$. carotovora subspecies

\begin{tabular}{lcccc}
\hline \multicolumn{1}{c}{ Characteristic } & \multicolumn{3}{c}{ Reaction of: } \\
\cline { 2 - 5 } & $\begin{array}{c}\text { E. carotovora } \\
\text { subsp. odorifera }\end{array}$ & $\begin{array}{c}\text { E. carotovora } \\
\text { subsp. carotovora }\end{array}$ & $\begin{array}{c}\text { E. carotovora } \\
\text { subsp. atroseptica }\end{array}$ & $\begin{array}{c}\text { E. carotovora subsp. } \\
\text { betavasculorum }\end{array}$ \\
\hline$\alpha$-Methylglucoside & $++^{a}$ & - & + & + \\
Palatinose & + & - & + & + \\
Melibiose & + & + & - & - \\
D-Arabitol & + & - & + & - \\
Sorbitol & + & + & - & + \\
Citrate & + & - & + & + \\
Inulin & - & + & - & + \\
Reducing sugars produced from sucrose & + & + & & + \\
Growth at $37^{\circ} \mathrm{C}$ & + & & & + \\
\hline
\end{tabular}

${ }^{a}+$, all strains are positive; - , all strains are negative.

The 11 strains associated with flavoring soft-rot of witloof constitute a tight genomic group. This group belongs to the $E$. carotovora genomic species since the type strain of $E$. carotovora was 68 to $69 \%$ related to strain CFBP $1878^{\mathrm{T}}$, with a $\Delta T_{m}$ of $3^{\circ} \mathrm{C}$. It is now accepted that strains of a species are about $70 \%$ related, with $\Delta T_{m}$ values that do not exceed $5^{\circ} \mathrm{C}$ (24). The $S 1$ nuclease method gives lower reassociation values than the hydroxyapatite method (12). Thus, the odorous soft-rot organism and $E$. carotovora subsp. carotovora may be members of one species. It should be noted that the same criteria would exclude $E$. carotovora subsp. atroseptica and $E$. carotovora subsp. betavasculorum $\left(\Delta T_{m}\right.$, more than $\left.7^{\circ} \mathrm{C}\right)$ from $E$. carotovora $\left(\Delta T_{m}\right.$, less than $\left.5^{\circ} \mathrm{C}\right)$. The delineation of these groups is being studied by workers in our laboratories.

$\Delta T_{m}$ values between 3 and $5^{\circ} \mathrm{C}$ are often observed between different subspecies of a species (11). Thus, the flavoring soft-rot organism qualifies as a subspecies of $E$. carotovora.

Witloof pathogens have been included in two numerical taxonomy studies. The first study was based on 421 Erwinia strains (among them were seven witloof pathogens, including three of our present collection) that were described by using 72 API tests (22). The witloof pathogen strains constituted subphenon 1E, which was closely related to but distinct from subphena $1 C$ ( $E$. carotovora subsp. carotovora) and $1 \mathrm{~A}$ ( $E$. carotovora subsp. atroseptica). The second study was based on 60 witloof Erwinia strains, and subphenon 1E contained 28 isolates (19).

Since the flavoring soft-rot witloof pathogen strains constitute a tight DNA subgroup which can be identified by using phenotypic tests, we propose that this organism should be recognized as a new subspecies, Enwinia carotovora subsp. odorifera. This subgroup is not suitable for pathovar classification since it contains isolates obtained from witloof chicory, celery and leeks (this study), and hyacinths (8).

Description of Erwinia carotovora subsp. odorifera subsp. nov. Erwinia carotovora subsp. odorifera (o.dor. if'er.a. L.fem.adj. odorifera, bringing odors, fragrant). Cells are gram-negative, nonsporeforming, peritrichous, straight rods. Facultatively anaerobic. Oxidase is not produced. Nitrates are reduced to nitrites. The species conforms to the definition of the family Enterobacteriaceae (10).

All strains grow on nutrient agar, producing colonies that are about $2.5 \mathrm{~mm}$ in diameter after $48 \mathrm{~h}$ at $25^{\circ} \mathrm{C}$ on YPDA medium. Colonies are circular, greyish (to yellowish on media containing sucrose or gelatin), slightly domed, and semitranslucent. All strains grow at $37^{\circ} \mathrm{C}$. Aminopeptidase is produced. Dextrose is fermented without gas production.
Voges-Proskauer test positive. Starch is not hydrolyzed. Polypectate gel is acidified and liquefied (Sutton medium). Cellulase is produced (carboxymethyl cellulose). Lecithinase and phosphatase are not produced. Indole is not produced from tryptophan. Reducing substances are produced from sucrose (Benedict reagent). Acid is not produced from inulin in peptone-water. Acid is produced in minimal mineral medium from lactose ( 2 to 3 days), trehalose ( 5 to 10 days), $\alpha$-methylglucoside ( 3 to 7 days), palatinose ( 2 to 3 days), melibiose ( 2 to 3 days), D-arabitol ( 2 to 4 days), and D-sorbitol (2 to 4 days). Alkalinization of mineral medium containing citrate occurs, but there is no alkalinization of mineral medium containing malonate. Esculin is hydrolyzed. $\beta$-Glucuronidase is not produced.

The following substrates are utilized as sole sources of carbon and energy on Biotype strips by at least 10 of the 11 strains: D-glucose, D-fructose, D-galactose, D-mannose, D-melibiose, sucrose, D-raffinose, lactose, lactulose, D-cellobiose, gentiobiose, 1- $O$-methyl- $\beta$-D-glucoside, D-ribose, L-arabinose, D-xylose, palatinose, L-rhamnose, D-arabitol, glycerol, myo-inositol, D-mannitol, D-sorbitol, 1-O-methyl$\alpha$-D-glucoside, D-saccharate, mucate, L-malate, citrate, D-galacturonate, $N$-acetyl-D-glucosamine, gluconate, DLglycerate, D-glucosamine, L-aspartate, L-glutamate, and $\mathrm{L}$-serine (in 3 or 4 days at $30^{\circ} \mathrm{C}$ ). Maltose, 1-O-methyl- $\alpha-$ galactoside, maltitol, D-turanose, D-glucuronate, 2-ketogluconate, succinate, fumarate, L-aspartate, L-glutamate, L-proline, and L-serine are utilized by some strains but not by all strains. The following substrates are not utilized within 4 days: $\mathrm{L}$-sorbose, maltotriose, $\mathrm{L}$-fucose, D-melezitose, L-arabitol, xylitol, dulcitol, D-tagatose, adonitol, D-lyxose, $i$-erythritol, 3- $O$-methyl-D-glucose, L-tartrate, D-tartrate, meso-tartrate, D-malate, cis-aconitate, trans-aconitate, tricarballylate, 5-ketogluconate, phenylacetate, protocatechuate, 4-hydroxybenzoate, quinate, gentisate, 3-hydroxybenzoate, benzoate, 3-phenylpropionate, $m$-coumarate, trigonelline, betaine, putrescine, 4-aminobutyrate, histamine, DL-lactate, caprate, caprylate, glutarate, 5-aminovalerate, ethanolamine, tryptamine, itaconate, 3-hydroxybutyrate, D-alanine, L-alanine, malonate, propionate, L-tyrosine, and 2-ketoglutarate.

The strains produce flavoring volatile compounds, such as propyl acetate, isobutyl acetate, isoamyl acetate, and actamyl acetate, when they are inoculated onto witloof leaves.

Isolated from soft rots of various plants, including $C$. intybus (cultivated for witloof production).

The type strain is strain CFBP 1878.

Description of the type strain. Strain CFBP $1878^{\mathrm{T}}$ was 


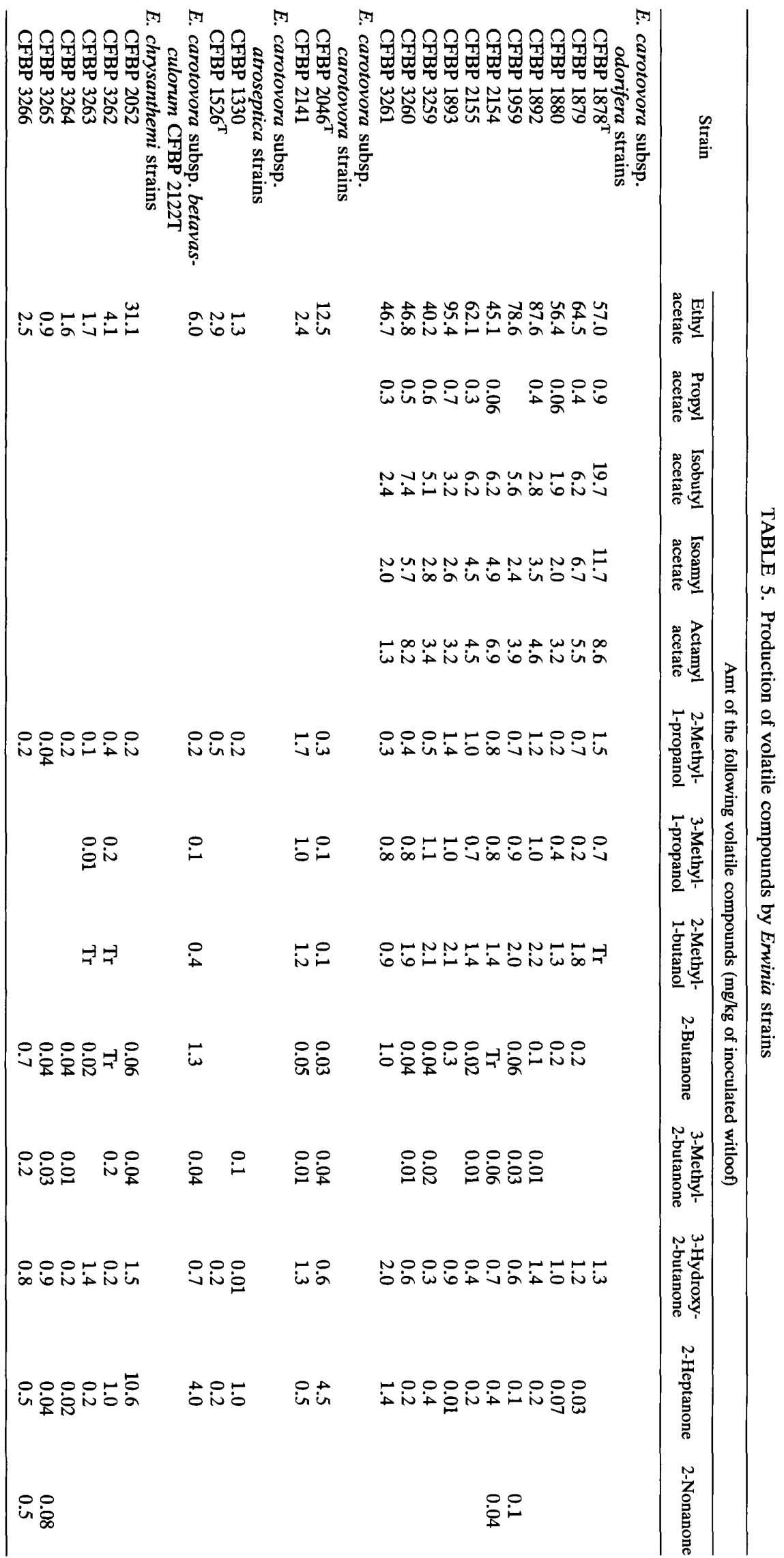


isolated from soft rot of $C$. intybus in Britanny (France) by R. Samson. This strain and five other strains (strains CFBP 1879, CFBP 1880, CFBP 1892, CFBP 1893, and CFBP 1959) have been deposited in the National Collection of Plant Pathogenic Bacteria, Harpenden, Great Britain, the International Collection of Microorganisms from Plants, Auckland, New Zealand, and the Laboratorium Microbiologie Rijksuniversiteit Culture Collection, Rijksuniversiteit, Gent, Belgium. The type strain has all of the properties given above for the subspecies. In addition, it utilizes as sole sources of carbon and energy succinate and fumarate in 2 days and 1- $O$-methyl- $\alpha$-galactoside and proline in 4 days. It does not utilize trehalose, maltose, D-glucuronate, and 2-ketogluconate in 4 days.

\section{ACKNOWLEDGMENTS}

We thank Michel Bourgeois (Plant Disease Diagnosis Service, Institut National de la Recherche Agronomique, Angers, France) for his keen sense of smell that suggested the study of volatile compounds.

\section{REFERENCES}

1. Bonnet, P. 1973. Pectolytic Enwinia. I. Rapid biochemical diagnosis. Ann. Phytopathol. 5:355-376.

2. Bourgeois, M. (Institut National de la Recherche Agronomique, Angers, France). 1978. Personal communication.

3. Brenner, D. J. 1978. Characterization and clinical identification of Enterobacteriaceae by DNA hybridization. Prog. Clin. Pathol. 7:71-117.

4. Brenner, D. J., A. C. McWhorter, J. K. Leete Knudson, and A. G. Steigerwalt. 1982. Escherichia vulneris: a new species of Enterobacteriaceae associated with human wounds. J. Clin. Microbiol. 15:1133-1140.

5. Cato, E. P., W. L. George, and S. M. Finegold. 1986. Genus Clostridium, p. 1141-1200. In P. H. A. Sneath, N. S. Mair, and M. E. Sharpe (ed.), Bergey's manual of systematic bacteriology, vol. 2. The Williams \& Wilkins Co., Baltimore.

6. Cerny, G. 1976. Method for the distinction of Gram-negative from Gram-positive bacteria. Eur. J. Appl. Microbiol. 3:223225.

7. Crosa, J. H., D. J. Brenner, and S. Falkow. 1973. Use of a single-strand-specific nuclease for analysis of bacterial and plasmid deoxyribonucleic acid homo- and heteroduplexes. J. Bacteriol. 115:904-911.

8. De Boer, S. H., L. Verdonck, H. Vruggink, P. Harju, H. O. Bang, and J. De Ley. 1987. Serological and biochemical variation among potato strains of Erwinia carotovora subsp. atroseptica and their taxonomic relationship to other $E$. carotovora strains. J. Appl. Bacteriol. 63:487-495.

9. Dye, D. W. 1968. A taxonomic study of the genus Erwinia. I. The "amylovora"' group. N. Z. J. Sci. 11:590-607.

10. Ewing, W. H. 1986. Edwards and Ewing's identification of
Enterobacteriaceae, 4th ed. Elsevier Science Publishing Co., Inc., New York.

11. Grimont, P. A. D. 1988. Use of DNA reassociation in bacterial classification. Can. J. Microbiol. 34:541-546.

12. Grimont, P. A. D., T. A. Jackson, E. Ageron, and M. J. Noonan. 1988. Serratia entomophila sp. nov. associated with amber disease in the New Zealand grass grub Costelytra zealandica. Int. J. Syst. Bacteriol. 38:1-6.

13. Grimont, P. A. D., M. Y. Popoff, F. Grimont, C. Coynault, and M. Lemelin. 1980. Reproducibility and correlation study of three deoxyribonucleic acid hybridization procedures. Curr. Microbiol. 4:325-330.

14. Kelman, A., and E. B. Cowling. 1967. Measurement of cellulase activity of plant pathogens using a viscosimetric technique, $p$. 190-192. In Sourcebook of laboratory exercises in plant pathology. W. H. Freeman and Co., San Francisco.

15. Lelliott, R. A., and D. E. Stead. 1987. Methods for the diagnosis of bacterial diseases of plants. Blackwell Scientific Publications, Oxford.

16. Samson, R., F. Poutier, M. Sailly, L. Hingand, and B. Jouan. 1980. Bacteria associated with soft-rot of witloof-chicory. Ann. Phytopathol. 12:311.

17. Samson, R., F. Poutier, M. Sailly, and B. Jouan. 1987. Caractérisation des Enwinia chrysanthemi isolées de Solanum tuberosum et d'autres plantes-hôtes selon les biovars et sérogroupes. Bull. Org. Eur. Méditerranéene Prot. Plantes/Eur. Mediterranean Plant Prot. Org. Bull. 17:11-16.

18. Thomson, S. V., D. C. Hildebrand, and M. N. Schroth. 1981. Identification and nutritional differentiation of the Erwinia sugar beet pathogen from members of Erwinia carotovora and Erwinia chrysanthemi. Phytopathology 71:1037-1042.

19. Vantomme, R., R. Sarrazyn, M. Goor, L. Verdonck, K. Kersters, and J. De Ley. 1989. Bacterial rot of witloof chicory caused by strains of Erwinia and Pseudomonas: symptoms, isolation and characterization. J. Phytopathol. 124:337-365.

20. Vantomme, R., V. Vermeulen, R. Sarrazyn, J. Swings, and J. De Ley. 1985. Bacterial rot on witloof chicory. Mededelingen van de Faculteit Landbouwwetenschappen Rijksuniversiteit Gent 50/3a:967-971.

21. Varns, J. L., and M. T. Glynn. 1979. Detection of disease in stored potatoes by volatile monitoring. Am. Potato J. 56:185197.

22. Verdonck, L., J. Mergaert, C. Rijckaert, J. Swings, K. Kersters, and J. De Ley. 1987. Genus Erwinia: numerical analysis of phenotypic features. Int. J. Syst. Bacteriol. 37:4-18.

23. Waterer, D. R., and M. K. Pritchard. 1984. Monitoring of volatiles: a technique for detection of soft rot (Erwinia carotovora) in potato tubers. Can. J. Plant Pathol. 6:165-171.

24. Wayne, L. G., D. J. Brenner, R. R. Colwell, P. A. D. Grimont, O. Kandler, M. I. Kritchevsky, L. H. Moore, W. E. C. Moore, R. G. E. Murray, E. Stackebrandt, M. P. Starr, and H. G. Truper. 1987. Report of the Ad Hoc Committee on Reconciliation of Approaches to Bacterial Systematics. Int. J. Syst. Bacteriol. 37:463-464. 